\title{
Exploring the Students' Critical Reflection Ability in Elementary School Place-Based Education Program
}

\author{
Hendra Erik Rudyanto \\ Department of Elementary Teacher Training \\ Universitas PGRI Madiun \\ Madiun, Indonesia \\ hendra@unipma.ac.id
}

\author{
Esti Yuli Widayanti \\ Department of Elementary Teacher Training \\ State Islamic Institute of Ponorogo (IAIN Ponorogo) \\ Ponorogo, Indonesia \\ estiyw@gmail.com
}

\begin{abstract}
The children developed by the process of socialization through various forms. One of them is the children socialization by interaction with 'place' in their environment. Children's interaction with 'places' in school might be facilitated by the Place-based Education (PBE) approach, in which there is a major concept of student interaction with the environment and surrounding communities. The PBE's nested context enables children to explore the closest environment to children in school to the community outside to provide students with awareness from local to global levels. This study explored students' ability to read social conditions (critical reflection) as their provision to be good adult citizens as a result of schools' ongoing outdoor learning program using PBE approach. The school program of PBE approach indicated by the use of five nested contexts. The research was conducted using qualitative approach with case study design at two elementary schools in Ponorogo and Magetan districts. These schools are implementing outdoor learning program using place-based education approach. The data obtained from the interviews, observations, and documentation assessed from the participants (teachers, students, principals, parents, and community). Researchers who play as a research instrument, then analyze the data by reviewing the results of interviews, field notes, and document review. Triangulations were sought among the multiple data sources. The research result showed that in their interaction with the environment and communities, students of the two sites experienced the development of critical reflection in four levels, i.e. passive adaptation, emotional engagement, cognitive awakening, and intention to act, in vary ways. The four levels experiences also in line with the Freire's critical consciousness model.
\end{abstract}

Keywords-children interaction with place; critical reflection ability; place-based education

\section{INTRODUCTION}

conducting the process through various forms. Interacting with 'place' in their environment is one of the form. Children connection with their 'place' could be happened in some different contexts. Place-based Education (PBE) approach gives five contexts which could be used as the learning sources, i.e: classroom, school building, schoolyard, neighbourhood, and larger community [1]. It is called as the nested context. In each context, students make some typical interaction with the physical environment and also with the person belong to the context. The PBE's nested context enables children to explore the closest environment to children in school to the community outside to provide students with awareness from local to global levels.

Since have correlation with the natural and human environments, the students are positioning themselves as a part or a member of the place they are live in. As a member of a community, students should take a part to be useful and could make great change to the better quality of life.

Place-based education approach enables tight interaction between students and some places as learning contexts. Understanding the real condition of the environment and the community, the students would make real action to solve the existing problems. Developing students' critical reflection as a main component of critical consciousness would bring the students to envision their community with maximum efforts they could do.

Critical reflection is one component of critical consciousness of the three components, components - critical reflection, political efficacy, and critical action. Critical reflection refers to a social analysis and moral rejection of societal inequities, such as social, economic, racial/ethnic, and gender inequities that constrain well-being and human agency. Those who are critically reflective view social problems and inequalities in systemic terms [2].

Critical consciousness is the term which has deep correlation with critical pedagogy proposed by Paolo Freire. Freire developed Critical Consciousness Theory in response to the illiteracy rates of impoverished Brazilian people. Ignorance is more than a lack of knowledge; it is also a lack of critical thinking skills. Knowledge serves a purpose within a society. Often, that purpose is to uphold conventional, often oppressive, ways of thinking. One of the purposes of traditional schooling is to create buy-in to the mainstream. Acquiring knowledge without critical thinking skills may indoctrinate a person into an oppressive culture. In addition to the acquisition of knowledge, critical thinking skills are necessary to resist oppression [3].

Watt also suggested to view critical reflection as result from an analysis of the structural causes of racial/ethnic, socioeconomic, and gendered disparities in health, well-being, educational attainment, wealth, and other domains [2]. 
Elementary school in rural area of East Java province have some similar characteristics of their natural resources, natural environment, and local community. Especially Ponorogo and Magetan regency, as they are in neighborhood area, they have just the similar characteristic of the environment, both the nature and the society.

The aims of this study are to view critical reflection as result of society condition of the research sites. The study examines the extent to which primary school students interact with the environment and surrounding communities in their learning, in order to improve the ability to read social conditions (critical reflection) as their provision to be good adult citizens. To answer the research question, the research analysed the data using critical consciousness model by Carlson et al which devide the development of the critical reflection into four levels [4].

\section{LITERATURE REVIEW}

In their writing about the current status and future direction about critical consciousness, Watts, Diemer, and Voight gave some statements about critical reflection as one component of critical consciousness [2]. The statements are described as the following. In our view, $\mathrm{CC}$ is composed of three components critical reflection, political efficacy, and critical action. Knowledge of $\mathrm{CC}$ and its component parts helps youth practitioners and scholars facilitate the process and expand understanding of the concept. Critical reflection refers to a social analysis and moral rejection of societal inequities, such as social, economic, racial/ethnic, and gender inequities that constrain well-being and human agency. Those who are critically reflective view social problems and inequalities in systemic terms.

Critical consciousness is the term which has deep correlation with critical pedagogy proposed by Paolo Freire. Freire developed Critical Consciousness Theory in response to the illiteracy rates of impoverished Brazilian people. Ignorance is more than a lack of knowledge; it is also a lack of critical thinking skills. Knowledge serves a purpose within a society. Often, that purpose is to uphold conventional, often oppressive, ways of thinking. One of the purposes of traditional schooling is to create buy-in to the mainstream. Acquiring knowledge without critical thinking skills may indoctrinate a person into an oppressive culture. In addition to the acquisition of knowledge, critical thinking skills are necessary to resist oppression [3].

Freire viewed the relation between reflection and action as reciprocal. Critical reflection is generally considered a precursor to critical action-people do not act to change their social conditions without some consciousness or awareness that their social conditions are unjust. He theorized that as oppressed people begin to analyze their social conditions, they would feel able and compelled to act to change them. Reciprocally, as people act on their social conditions they would gain a more sophisticated understanding of structural oppression. Thus, as critical reflection grows, critical action follows and vice versa in the cyclical process of $\mathrm{CC}$ development. However, there will also be times when critical action fails to yield the desired result, which can lead to frustration and cynicism, rather than a greater awareness of societal inequities [2].

Freire, stated that reflection results in "critical consciousness" learners become actors, not observers, and authors of their own decisions the way to "praxis" (actions informed by reflection) [5].

So, it can be concluded that critical reflection is a component of critical consciousness as constructed by Freire, which has vice versa correlation with critical action, as the other component.

Of the three components, critical reflection is the most neglected in youth civic engagement research, while being a central component of $\mathrm{CC}$. Therefore, it will receive the most attention here. Rather than limiting analysis to "blaming the victim" and other individualistic explanations for societal inequities, critical reflection results from an analysis of the structural causes of racial/ethnic, socioeconomic, and gendered disparities in health, well-being, educational attainment, wealth, and other domains. It also frames social inequalities in a historical context, with an emphasis on its root causes social structures' policies and practices. Returning to Freire's perspective, "The more accurately men grasp true causality, the more critical their understanding of reality will be" [5].

We found no scales designed especially to measure critical reflection. However, social psychological theories of attribution are particularly relevant to critical reflection research. People make causal attributions to make sense of social problems and inequalities, such as disparities between poor people and rich people. These attributions may be more individual (e.g., we have an equal social system and opportunities, therefore the limited effort and/or ability of groups on the lower rungs of society cause social problems and inequalities) or may be more structural (e.g., we have an unequal social system and opportunities, therefore social systems, policies, and historical conditions cause social problems and inequalities). People with greater levels of critical reflection make more structural attributions for social problems and group disparities.

Neville, Coleman, Falconer, and Holmes repurposed an existing measure to assess individual and structural attributions for the collective economic and social position of African Americans. Individual attributions were represented by items such as "lack of motivation and unwillingness to work hard" and structural attributions by endorsement of "lack of educational opportunities" and similar items. Individualistic attributions were associated with a "color blind" racial ideology, where the existence of racism is denied or minimized among African American adults. Although these authors did not explicitly align their "attribution of blame" scale with CC theory, or sample young people, we see it a promising approach to assess critical reflection [6].

Another construct associated with critical social analysis is social dominance orientation (SDO), which refers to the attributions people make for groups' collective social position [7]. The SDO scale measures support for group-based inequalities and dominance and has been associated with ideologies such as the "meritocracy myth," racist attitudes, and 
social Darwinism. If scored in reverse, SDO becomes a measure for the rejection of such views. Sample items include "It's probably a good thing that certain groups are at the top and other groups are at the bottom." Rejection of ideologies that favor social inequality has been associated with greater levels of critical reflection among urban adolescents [8]

Similarly, critical reflection (also measured by lower SDO scores) was associated with greater progress in career development among urban adolescents, suggesting that critical reflection may help marginalized youth overcome external barriers to success in school and work [8].

Four Steps to think about Critical Reflection recommended by Jacoby [9], especially for designing and facilitating critical reflection in the course, are as follows: 1. Identify desired learning outcomes -Begin with the end in mind, and state your learning outcomes in concrete, measurable terms. Make it clear what students can expect to gain. "Critical reflection is something you will want to consider for learning outcomes around more complex dimensions of reasoning, developing enhanced understanding, questioning knowledge, theories, and assumptions," she says; 2. Design reflection activities to achieve learning outcomes - Here you must consider when, where, and how often the reflection will occur; who will facilitate and participate in the reflection; and what mediums will be used for the reflections; 3. Engage students in reflection. During the actual engagement portion, it's important to provide a balance of challenge and support. As you provide students with prompts for reflection, you want to guide them to incrementally higher levels of complexity of thinking, analyzing, and reasoning; 4. Assess learning through critical reflection - Use formative assessment to make periodic checks of the reflection process against the designed learning outcomes. If necessary, refine the desired learning outcomes along the way, shift reflection strategies or change the reflection mechanism. Some of the questions addressed at this step are: What products will demonstrate learning? What criteria will be used to assess learning? What assessment mechanisms will be used? How will reflections be factored into grades?

Qualitative and participatory action research has approached the assessment of critical reflection through the identification of themes. Interventions are often part of the endeavor and researchers are more likely to be explicit in their use of CC concepts and terms. As their participants reflect on their lives in their own words, they do not necessarily distinguish these three CC components. Carlson, Engbretson, and Chamberlain employed a photo voice methodology with both youth and adults of a low-income urban area in the United States, using the participants' explanations of their community photographs as data to explore critical reflection. Their analysis led to a four-stage understanding of critical reflection: (1) passive adaptation, (2) emotional engagement, (3) cognitive awakening, and (4) intention to act [4]. An example of "cognitive awakening" is the increased awareness of connections between local economic activity and community conditions. One participant demonstrated cognitive awakening in her understanding of how poor community conditions are perpetuated by local businesses: "The owners won't participate in, or contribute to, anything we do in the neighborhood. Why do we support them when they grab their children, their fine expensive cars, and our money and dash out of the community before dark every day?" (p.845).

Making this type of attribution for social problems is indicative of more advanced critical reflection.

Action researchers have sought to enhance $\mathrm{CC}$ as they learn about it, fostering sociopolitical development among youth in an effort to lessen the risk of negative health or psychosocial outcomes. In a participatory action research project, engaged indigenous Canadian youth in the creation of health information videos. According to the authors, the young people expanded their notions of health literacy to their own cultural traditions, developed a more critical perspective on issues in their community, and some reported changes in their personal health behavior [10]

Watts, Griffith, and Abdul-Adil coached high schoo students to decode social messages in "gangsta" rap music videos. All too often, these representations of youth emphasize shortcomings in the character of individuals rather than social systems [11]. Similarly, Campbell and MacPhail's CC intervention engaged South African youth in discussions of gender roles to help them move the "causal" explanation for human immunodeficiency virus (HIV) infection from a more personal decision-making problem to one that took into consideration cultural norms that pressured young women into unsafe sex. Their work also shows the power of a Freirean approach in helping young people examine their social privilege (e.g, as males, heterosexuals, affluent, etc.) as well as their marginalization. Campbell and MacPhail recommend that peer HIV education include $\mathrm{CC}$ education and reflection, particularly on notions of masculinity and femininity [12].

The connection between critical reflection on social identity and internalized oppression or privilege is also important. Guessous and Watts analyzed young people's applications to a selective, nationally recognized training program for community organizers of color. They found that participants' interest in social justice organizing stemmed from critical values instilled through family in childhood and adolescence, a salient and positive social identity, personal experience with injustice, and critical reflection. Watts' analysis of this dataset suggested a synergy between critical reflection and the rich and varied experiences with social identity and activism in these settings; his findings suggest that researchers need to assess opportunities for civic and political engagement in the social and institutional environment as well as psychological factors in political development [13].

Critical Pedagogy of Place is reviewed by several figures, including G.A Smith in his article titled Place-Based Education: Learning to be Where We Are "provides an overview of the topic of PBE for the public. In this article for the first time the term 'place-based education' is published in an educational journal. At the end of this article, Smith argued to use the place as a starting point for curriculum development and to explain justice as the goal [14]. Smith explains to the reader the many aspects of the NTE, including the broader definition of the NTE and the historical movement of the PBE to date. Smith represents the difficulties of current school administrators to initiate and support students to engage on the 
topic of real-world controversy and student activity. Smith's message is that there is a pedagogical shift in student engagement that is real/meaningful to a particular topic, a question and a need for policy change [15].

David A Gruenewald discusses the convergence between critical pedagogy and the PBE and argues in terms of 'critical pedagogy of place'. This Grunewald article becomes a monumental work that fills the gab between the field of education and provides the idea that there is a complementary relationship between critical pedagogy and place learning. Gruenewald justifies convergence through the relationship between social activism and environmental ethics. The key point of this idea is 'decolonization' and 'reinhabitation' is seen as a method for dealing with the environment [16]

Stevenson in his article entitled 'Schooling and Environmental Education: contradiction in purpose and practice, summarizes the conflict between current educational goals and environmental education. This article, originally written in 1997, clearly states many aspects of the current school system and is encouraged to integrate environmental education into the mainstream curriculum [17].

Stone and Barlow write for readers to introduce the concept of PBE through real-world examples. This work is also a writing that introduces the mission and philosophy of the Center of Ecoliteracy. Social justice and activism are the themes presented. This text also represents the ecojustice movement occurring in the larger world of the PBE as described by Grunewald [18].

The compilations of the PBE roots are presented in various essays by Grunewald and Smith [19]. This paper also discusses the implications of how the concept of decolonization and reinhabitation may be applicable in the educational process. This paper also questions the current educational objectives by offering ideas about new local movements. It also seeks to contribute to PBE theory and practice through stories and examples.

In Indonesia, research on critical awareness of environmental issues is done by Ramadhani, et al who examines the critical awareness of Madurese towards the implementation of mosquito nest eradication as a vector of dengue fever [20]. The results showed that: knowledge of mosquito nest eradication still low; research subjects have low attention to the surrounding environment; research subjects whose families had been exposed to dengue fever, tried to actively seek information related to the fever; the research subjects do not take action independently (do not clean the water of the refrigerator, hang up clothes in the room, lack the environment, do not use mosquito wire, do not spread abate powder to the water reservoir)

In concern with the students'ability of critical reclection of their environment, our research explored a four-stage understanding of critical reflection of the students in the two sites of research's subject, especially when they (students) acquintanced with PBE learning program. The four stage are based on the four stage understanding of critical reflection by Carlson, Engbretson, and Chamberlain [4], i.e: (1) passive adaptation, (2) emotional engagement, (3) cognitive awakening, and (4) intention to act.

\section{METHOD}

This research accommodated a case study in two elementary schools of two similar districts in East Java, Indonesia, i.e.: Ponorogo and Magetan regency. These two areas are in neighbourhood which have almost similar natural environment condition. The different is how they manage their outdoor learning to engage with the society. The assumption is that they have different characteristic of the societies. The two schools also differ in managing their outdoor learning process in be half of the five (nested) contexts.

Case study was engaged to make an examination which would give a better description about the learning program held by the schools. In this case, what to be examined was the effect of the learning program.

In each district, one teacher participated in this study. He is a classroom teacher of $5^{\text {th }}$ graders. Each teacher had been executing the outdoor learning program for two years, since the adapted the newest Indonesian education curriculum (Indonesian K13). The first school, a Ponorogo one, is a non traditional teacher, a fresh graduate from elementary teacher training institute. The second teacher, a Magetan one, is a senior elementary teacher, who has been being a professional teacher, proven by having a teaching certificate from the national educational ministry. Both of them carry out a typically outdoor learning program in some of their instructional activities, which identified by the authors to be following the concept of the nested context since they collaborated the outdoor learning with some place and community context around the classroom from the nearest to the more far places and communities. The teachers were different by their age, but they had similar experience of attending some workshop/training of the newest curriculum.

The students as the participants were selected because they are the class member of the research subject. They were engaged with the class learning program, the outdoor learning which using nested context. The context is the main concept of place based education which using five different places where students could learn in the places and with the community belong to them. The numbers of the first school's participant student were 15 , seven were girls and the rest were boys. While in the second school, there were 11 girls and 14 boys. They were all in the same age.

Adapted the case study by Bouck, the researchers had the role of the researcher as participant observers. The researcher attempted to maintain more of an observer rule. The role, then, shifted to more than an observer's role. The researcher had to assist with the instructional activities [21].

Data was collected through triangulation, both different participants and method of collecting data. For each school, data were collected from observation and interview with the participants, the teachers and the students. The data was also collected by doing some observation along the day when the learning program was held. In this research, it was used the 
purposive sampling to decide what to observe and when were. In brief, the data were collected using some instruments in the form of interviews, field notes, and researcher reflection notes.

Data analysis began by collecting and ordering the data (in the form of interviews, field notes, and researcher reflection notes) based on the site (the school). Then, the hard copies were organized in chronological order by school site. By observing the pattern occurred for each school, the data were parsing and then making the comparison between two schools. And among the multiple data sources from the vary data collection methods, triangulation was applied. Interview was the main form of data sources, while observation and documentation were used to support or challenge the result of the interviews.

The interview was using the open-ended questioning techniques which encourage broader and deeper understandings; encourages active participation and evaluation of one's own work

\section{RESULT AND DISCUSSION}

\section{A. Result}

The result of this study are led to a four-stage understanding of critical reflection of the students in the two sites of research's subject. The four stage are based on the four stage understanding of critical reflection by Carlson, Engbretson, and Chamberlain i.e: (1) passive adaptation, (2) emotional engagement, (3) cognitive awakening, and (4) intention to act [4].

1) Passive Adaptation: In Passive adaptation, frustrations turn to emotional apathy, and blame is placed on others; the cognitive-emotional interpretation of events is helplessness [4]. Passive adaptation can be reflected as a community norms steeped in apathy, dependency thinking, and an intense distrust of themselves, their neighbors, and the larger community. The rhetorical moral message "We have to do something" is undermined by the cultural norms of distrust and blame that are pervasive and destructive to all attempts at individual and collective action.

Some participants in the first school realized that they have to do something with the rubbish around the school and their neighborhood, but they think they are too small to think the rubbish problem. Their family and community usually think they know nothing.

The rest of the participants, said that the can do some simple action for the rubbish, such as take the rubbish into the trash can, or differentiate the rubbish based on the characteristic. The exceptional was when they were in the classroom and in the school building. They seemed more confident to do something with the rubbish without getting any involvement from the older family or society.

In contrary, in the second school, all of the participants said that they were able to do something with the rubbish, including cycling them into functional things/handicrafts. In all five contexts, (the classroom, the school building, the schoolyard, the neighborhood, and the society), the participants of the second site just said the same. According to the teacher of the second school site, students had been familiar with the garbage work since they were in second grade. But working with the society was still new to them.

2) Emotional Engagement: If the passive adaptation is categorized as lower level of critical reflection (as variable of critical consciousness), so these three levels, emotional engagement, cognitive awakening, and intention to act, are categorized into the higher one. Emotional engagement is the level of critical reflection development of how the participant had feeling about the environmental problems and thought who had been responsible for it.

In the first school site, at the first context (the classroom), the participants though that they were responsible for the messy if they are themselves are the messy maker. They though they didn't responsible of the messy made by others. At the school building, the students started to think they were responsible for the building cleanness but did not think yet about the big think like how to manage the garbage. They were just thought of the little think like to collect the plastic bottles and sold them to scavenger.

In the second school site, when the students were asked about the school garbage they met in the building, they answered that anybody must be responsible for it, not just someone who made the garbage existed. So for most all of students as participant, everybody was responsible for the cleanliness of the classroom, the school building, and the schoolyard.

The participants in the first school also were interviewed about the garbage they met in the neighborhood and society. Just same with their answer about garbage in school building, most all of them also answered that somebody must be responsible for the garbage, including them as the part of the society. They also said that parents and adult people also responsible to make the cleanliness.

The data of emotional engagement in neighborhood and society were also received by observing the lesson instruction process. The lesson was thematic model in learning civic, social study, and science lesson. The theme was 'caring the social environment'. Based on the observation, it was showed that the students as research's participants had been started to engage them emotionally with the social condition. When they saw the domestic garbage in the street, they asked the teacher about it. They also asked how came the rubbish become there while it was far away from the housing. The students also had the same respond when they saw the ditch which full of domestic garbage.

3) Cognitive Awakening: "Cognitive awakening" is the increased awareness of connections between local economic activity and community conditions [4]. In this study, these definitions can be understanding as the increase awareness of connection between school/students or local activity and community condition.

Based on the interview as the main form of the data collection, almost all of the students said that they become more aware of the community condition through the learning 
process which engaged them with the society outside the school. As for the topic of the lesson were about the environment sustainability, the students seemed to increase their awareness of that there are any connection between local activity and community condition.

One participant demonstrated cognitive awakening in her understanding of how most of people in rural area did not differentiate their daily rubbish into its characteristic, organic or inorganic waste. But they manage their waste based on what their parents do, for example if they have banana peels rather than throw them away into domestic rubbish place, better for them to give the peel for domestic animal they have (sheep and cow).

Another participant from the first school also said that their family always gives the vegetable rubbish for their chicken in the next morning.

The participant of the first school also realized that the community in their neighborhood (rural area) did not manage the bottle water to be cycled. They just throw them away into domestic rubbish place, and burn them periodically.

From the learning activity that the students have to find plastic rubbish from the domestic rubbish place around the community house, the students found the rest of burning plastic. But they also found the plastic bottles which not be burn yet.

In the second school, there was another activity that was to interview the community about their rubbish management. It was found from the students' note that they did not sell the plastic bottle rubbish because they can still use it for refill bottle to be used when they work in the field. They also did not sell the bottle because the price was too cheap. Rather than gather them together they prefer to throw them away into domestic rubbish place and burn them periodically. When interviewed, some of students can explained their finding but some still confused how to summary or retell their finding.

4) Intention to Act: The data of 'the intention to act' were acquired by the interview with the participants as the main form of data gathering. While interview with the teacher and the lesson process observation were the other forms to get the data to complement or to compare. The data collection forms were intended to compile the data base on the definition of the 'Intentions to act', i.e: Emotions of hope are evident, and participants are able to envision and articulate a new future; the cognitive-emotional interpretation of events is "We are part of the solution" [4].

Based on the interview, the participants of the first school site shifted to an even higher level of critical reflection, intention to act. The students are able to make a vision of a new future in a hopeful emotion. It was stated that they were also part of the solution.

From the first school site, almost all of the participant students said that actually they could make an action to clean the ditch, but their parents seemed that they did not have to do that. They thought that their parents would say that it was adult responsibility. They thought they were not allowed to do such 'bigger' things, they are still children. They also said that they would get the ditch clean if their parents give permit.

The similar data finding also found in the second school site. The second interview with the same students concluded that they had intention to act to make the environment kept clean. Some participants said that the environment, both of the school and the community, would be better if all of the member of the community take responsibility, including them as member of the school and the community. They also said that even children can do such bigger things, like reduce, reuse, and recycle the garbage.

The teacher stated that students had been given some skill to reduce, reuse, and recycle the garbage from the environment because they managed le lesson of 'prakarya/keterampilan' as part of the thematic project of the curricular theme 'caring the environment' of the $3^{\text {rd }}$ grade.

\section{B. Discussion}

This study examines the extent to which primary school students interact with the environment and surrounding communities in their learning, in order to improve the ability to read social conditions (critical reflection) as their provision to be good adult citizens.

In summary, this research finding support the theory of critical consciousness (by Freire) that there were a shifted movement from basic level of consciousness (passive adaptation) to the three higher levels. While Freire categorized the level of consciousness into three levels, i.e. [22]: magic, naive, and critical level of consciousness, this research finding followed the model of critical consciousness by Carlson et al. which categorized the level into four: passive adaptation, emotional engagement, cognitive awakening, and intentions to act [4].

First level of consciousness by Freire called Magic level of consciousness: People are trapped by assumed inferiority and live within a culture of silence; passive acceptance actively contributes to their oppression.

In passive adaptation by Carlson et al [4], community norms steeped in apathy, dependency thinking, and an intense distrust of themselves, their neighbors, and the larger community. The rhetorical moral message "We have to do something" is undermined by the cultural norms of distrust and blame that are pervasive and destructive to all attempts at individual and collective action.

Of the two sites, there were different thought of the students of how they could participate in solving the environment problem, around the school or far away in society. The first site participants were in apathy and distrust of themselves. They did not think they could manage the garbage problem, since they still children age. Managing domestic garbage is such a big problem which was the adults' task, they thought.

It was stated that the first week of the implementation of the outdoor learning program, the student seemed to be confuse when they were asked about how they should do with the garbage around the society. The students confuse was about 
their condition of being young man who is not have obligation to manage the garbage that exist in their society. This condition of the children, undermined by the cultural norms of distrust [4]. The students though they are the member of the society which not yet have any responsibility of their environment. The participants, as members of the society felt in inferiority, and they live as passive citizen, as they were still children [22].

Of all the five contexts of the places (place-based education context), at the beginning of the lesson program which apply the places context as learning sources, the students as research participants were in passive adaptation when they pose themselves as a member of society, while when they were in school area, they felt more confident.

The second level as the higher levels of the development called the emotional engagement [4]. Emotional engagement is the level of critical reflection development of how the participant had feeling about the environmental problems and thought who had been responsible for it. In the two cases, the students were move out of passive adaptation. They kept in their mind about the problems the environment faced, both in school and in larger society. They also started to think who had been responsible for the cleanliness of their environment.

The higher level of the development is the "Cognitive awakening", i.e. the increased awareness of connections between local economic activity and community conditions [4]. In this study, the definition can be understood as the increase awareness of connection between school/students or local activity and community condition. The students became aware of local activity. They seemed to increase their awareness of any connection between local activity and community condition. The community condition where the students lived had been realized by the students while they did the lesson learning process. They finally found that community they lived in have some characteristic which directed them to some unique activities, especially how manage the garbage. Compare it to the level of critical consciousness by Freire [21], this condition is in the level of 'the critical level of consciousness Step 1, i.e. Unveiling oppression. Individuals gradually become conscious of their own perceptions of reality and deal with it critically.

The highest level of the critical reflection development is the 'Intentions to act', i.e.: Emotions of hope are evident, and participants are able to envision and articulate a new future; the cognitive-emotional interpretation of events is "We are part of the solution" [4]. This level has been reached by the students while they applying the instruction method of place-based education in all five contexts. All of the students agree and can define the environment condition they should have ideally. Students also reject some condition of garbage messy to be ideal condition. These student's reaction met the demand of Critical level of consciousness, Step 2 by Freire (Rejecting damaging images. Replacing damaging self-image with pride and acquiring skills for self-reliance to function autonomously). The students stated that ideally, the environment should be clean and the garbage were well managed by the reduce, reuse, and recycle program [22]. They also said that they should participate with the program.
In summary, the analysis of this research data, describes the development of critical reflection of the participants based on a model of critical reflection development (critical awareness) of [4]. Analysis of Carlson et al. delineated three distinct, hierarchical levels of cognitive interpretation that moved people out of passive adaptation. The analysis of Carlson et al is also analogous to the degree of hierarchical critical awareness of Freire's theoretical framework [22]. It can be summarized that the development of critical reflection as part of the students' critical awareness in this study is in line with the development presented by Carlson et al, that students experience three higher levels of passive adaptation: emotional engagement, cognitive awakening, and intention to act. Slight differences occurred in the school sites studied because of the students' initial knowledge of environmental management, especially waste management. With better knowledge on the second school site, make them more confident to face life in society. However, the five context-based learning programs played an important role in supporting the development of students' critical reflection on their role as part of the community.

The result of this research support that the critical pedagogy (through the critical consciousness accomplishment) should apply in school program, since the basic education (such as pre and primary school). The research by Luter et al. also showed the connection between the critical consciousness and school [23]. It investigated how the school program which apply critical pedagogy by developing critical consciousness can increase lower achievers' academic performance. The research also showed that the critical consciousness had a close connection with environment caring effort. This research in place-based education were in accordance with this.

The future researches should try to make deep analysis of how students' critical reflection or critical consciousness (as a whole concept) on the newest issues of environmental problems. The empirical research result can be more practical to be used as a basis to improve instructional process. The next researches are also expected to analyze which instructional methods are best to apply to improve or to reveal students' critical consciousness on environmental problems, mostly as best practices of the place-based education approach.

\section{CONCLUSION}

This study examines the extent to which primary school students interact with the environment and surrounding communities in their learning, in order to improve the ability to read social conditions (critical reflection) as their provision to be good adult citizens The research result showed that in their interaction with the environment and communities, students of the two sites experienced the development of critical reflection in four levels, i.e. passive adaptation, emotional engagement, cognitive awakening, and intention to act, in vary ways. The four levels experiences also in line with the Freire's critical consciousness model. The development of the critical reflection was engaged in all contexts of the place-based education approach. 


\section{REFERENCES}

[1] C.A. Buxton and E.F. Provenzo, Place-based science Teaching and Learning 40 activities for K-8 Classroom. SAGE Publication, 2012.

[2] R.J. Watts, M. A Diemer, and A. M. Voight, Critical consciousness: Current status and future directions. In C. A. Flanagan \& B. D. Christens (Eds.), Youth civic development: Work at the cutting edge. New Directions for Child and Adolescent Development, vol. 134, pp. 43-57, 2011.

[3] Newark community collaborative board, Critical Consciousness Theory, Retreived forom: http://newarkccb.org/framework/criticalconsciousness-theory/

[4] E.D. Carlson, J. Engebretson, and R.M. "Chamberlain, Photovoice as a social process of critical consciousness," Qualitative Health Research, vol. 16, no. 6, pp. 836-852, 2006.

[5] P. Freire, Education for Critical Consciousness. New York: Seabury, 1973.

[6] H.A. Neville, M.N. Coleman, J.W. Falconer, and D. Holmes, "Colorblind racial ideology and psychological false consciousness among African Americans," Journal of Black Psychology, 31, pp. 27-45, 2005.

[7] F. Pratto, J. Sidanius, L. M. Stallworth, and B. F. Malle, Social dominance orientation: A personality variable predicting social and political attitudes. Journal of personality and social psychology, vol. 67, no. $4,741,1994$.

[8] M.A. Diemer and D.L. "Blustein, Critical consciousness and career development among urban youth," Journal of vocational behavior, vol. 68, no. 2, pp. 220-232, 2006.

[9] B. Jacoby, How can I promote deep learning through critical reflection? Magna Publications, 2010

[10] S. Stewart, T. Riecken, T. Scott, M. Tanaka, and J. Riecken, "Expanding Health Literacy: Indigenous Youth Creating Videos," J Health Psychol, vol. 13 , no. 180,2008 .

[11] R.J. Watts, D.M. Griffith, and J. Abdul-Adil, "Sociopolitical Development as an Antidote for Oppression-Theory and Action," American Journal of Community Psychology, vol. 27, pp 255-271, 1999.
[12] C. Campbell and C. MacPhail, "Peer education, gender and the development of critical consciousness: Participatory HIV prevention by South African youth," Social Science \& Medicine, vol. 55, no. 2, pp 331-345, 2002.

[13] C.A. Flaganan, and B.D. Christens (ed) (2011). Youth Civic Development: Work at the Cutting Edge: New Directions for Child and Adolescent Development, Number 134 Volume 113 of J-B MHS Single Issue Mental Health Services, John Wiley \& Sons, 2011

[14] G.A. Smith, Place-based Education. Phi Delta Kappan 83.8 (Apr 2002): 584-594, 2002

[15] G.A. Smith, "Place-based Education. Breaking through the constraining regularities of public school," Environment Education Research, vol. 13, no. 2 , pp. 189-207, 2007.

[16] D.A. Gruenewald, "The Best of Both World: A Critical Pedagogy of Place," Educational Researcher, vol. 32, no. 4, pp. 3-11, 2003.

[17] R.B. Stevenson, "Schooling and environmental education: contradictions in purpose and practice," Environmental Education Research, vol. 13, no. 2, pp. 139- 153,2007

[18] M.K. Stone and Z. Barlow, (Eds.). Ecological Literacy: Educating Our Children for a Sustainable World. San Francisco: Sierra Club Books, 2005.

[19] Gruenewald, D.A. "The best of both worlds: a critical pedagogy of place," Environmental Education Research, vol. 14, no. 3, pp. 308-324, 2008.

[20] F. Ramadhani, R. Yudhastuti, and S. Widati, "Critical Consciousness of Madurese Society against Implementation of Mosquito Nest Eradication as Vector of Dengue Fever," Dama International Journal, 88-89, 2017.

[21] E. Bouck, "Exploring the Enactment of functional curriculum in selfcontained cross-categorical program: A case study," The Qualitative Report, vol. 13, no. 3, pp. 495-530, 2008.

[22] P. Freire, Pedagogy of the oppressed (MB Ramos, Trans.). New York: Continuum, 1970

[23] N.R. Pinelli, J.E. McLaughlin, S.L. Chen, D.N. Luter, J. Arnall, S. Smith, and L.B. Amerine, "Improved organizational outcomes associated with incorporation of early clinical experiences for secondyear student pharmacists at an academic medical center," Journal of pharmacy practice, vol. 30, no. 1, pp. 99-108, 2017. 